\title{
Paideusis
}

\section{"The Abandoned Generation: Democracy Beyond the Culture of Fear " (Henry A. Giroux)}

\section{Emery James Hyslop-Margison}

Volume 15, Number 1, 2006

URI: https://id.erudit.org/iderudit/1072700ar

DOI: https://doi.org/10.7202/1072700ar

See table of contents

Publisher(s)

Canadian Philosophy of Education Society

ISSN

0838-4517 (print)

1916-0348 (digital)

Explore this journal

Cite this review

Hyslop-Margison, E. (2006). Review of ["The Abandoned Generation:

Democracy Beyond the Culture of Fear " (Henry A. Giroux)]. Paideusis, 15(1),

113-115. https://doi.org/10.7202/1072700ar viewed online.

https://apropos.erudit.org/en/users/policy-on-use/ 
Review of

\title{
The Abandoned Generation: Democracy Beyond the Culture of Fear
}

by Henry A. Giroux, New York: Palgrave Macmillan, 2003

\author{
EMERY HYSLOP-MARGISON \\ Concordia University
}

The terrorist attacks that occurred on September 11, 2001, dramatically transformed the face of American culture in a variety of important ways. They shattered the widely held assumption, for example, that citizens of the world's greatest military power are insulated or protected from the daily violence that ravages so many lives throughout an increasingly impetuous global community. Aside from this most obvious consequence of the tragedy, the events of 09/11 also triggered a series of domestic policy decisions that collectively undermine the civil liberties and social welfare of many US citizens.

In The Abandoned Generation: Democracy Beyond the Culture of Fear, Henry Giroux describes how the Bush administration has effectively exploited the events of September 11, and the widespread fear they generated, to launch a concerted attack against the rights and freedoms of US citizens. With the passage of the Homeland Security Act, the police, the Central Intelligence Agency and the Federal Bureau of Investigation have been granted virtually unlimited powers of search, seizure and detention. Even more chilling perhaps is the emergent view that dissenting voices speaking against present US foreign and domestic policy decisions during this period of national crisis are subversive, anti-patriotic and sympathetic to terrorism. Giroux recalls that the City University of New York trustees and chancellor openly condemned their own faculty members for suggesting US foreign policy was a contributing factor to the terrorist attacks. The concerted attempts to muzzle democratic dissent are especially disconcerting when endorsed by the wife of the vice-president, Lynne Cheney, who publicly castigated the chancellor of New York City schools for suggesting that the "terrorist attacks demonstrated the importance of teaching about Muslim cultures" (p. 22).

As Giroux correctly observes, the undermining of democratic dissent revealed in such acts is a troubling development at a time when human capital assumptions and neo-liberal ideology are reducing education to instrumental modes of learning that naturalize corporate culture. The idea that uncritical acquiescence to government decisions and policy somehow represents patriotic behaviour is a perilous and menacing perspective that poses a genuine threat to democratic ideals. The role of education within healthy, meaningful democracies includes the unrestrained questioning of government policies and actions. Giroux emphasizes this point by arguing that suppressing an educational culture of intellectual questioning and political dissent is contrary to the most basic principles of an effective democracy, largely dependent on an education system that encourages dialogue, critique, opposition and social justice.

The traditional reaction by those in the US government to perceived threats to national security has been that of instituting educational policies that advance conservative political ideology. The events

(C) Copyright 2006. The author, Emery Hyslop-Margison, assigns to Paideusis the right of first publication and educational and non-profit institutions a non-exclusive license to use this document for personal use and in courses of instruction provided that the article is used in full and this copyright statement is reproduced. Any other usage is probibited without the express permission of the author. 
of September 11, 2001, represent yet another example of this historical trend. Giroux attacks the conservative educational agenda advanced by the Bush administration for launching a war against the nation's youth through Title I initiatives. He notes that the words "democracy" and "citizenship" are entirely absent from Bush's 28-page education plan No Child Left Behind. Rather than providing funds to decrease class size, expand pre-school programs, and increase available resources to improve social services for economically disadvantaged students and families, Bush's plan, through increased testing that directs available financial resources to corporate test designers, lays the blame for academic underachievement squarely at the doorstep of underpaid teachers and poorly funded schools. Of course such a move provides conservatives and their corporate allies with the ideological advantage of diverting public attention from the deeply rooted structural causes of low academic achievement and attainment. It is far simpler and more ideologically effective to blame "bad" teachers and "failing" schools than to seriously address and repair the class based system actually causing the widespread academic inequality in the US.

Giroux includes two chapters in the book that analyze popular films as public pedagogy. The trenchant analyses he provides reveal how films act as a vehicle for social critique, as evidenced by his analysis of Ghost World, and how they frequently convey dangerous stereotypical representations of gender and ethnicity as illustrated in his critique of Baby Boy. Film has clearly emerged as the dominant cultural text in contemporary society, and Giroux's analyses provide excellent examples of how educators might exploit this medium to foster meaningful social critique in their classrooms.

Many of us working in the contemporary university milieu have at least some gnawing notion that our traditional academic and intellectual freedoms are being eroded by a prevailing neo-liberal ideology bent on reducing higher education to technical training and transforming the role of faculty to entrepreneurial researcher. The university has increasingly become a site of technical training, labour market preparation and instrumental learning, and far less an institution that provides public spaces for social, moral and political dialogue. Giroux adds an important voice of resistance to this troubling trend, complementing Stanley Aronowitz's recent contribution The Last Good Job in America by advocating the need to reclaim the university as a site of democratic dialogue, social leadership and public influence.

The Abandoned Generation: Democracy Beyond the Culture of Fear provides many examples of how corporate influence and human capital assumptions increasingly frame policy and personnel decisions at institutions of higher learning. Giroux cites Kmart's approval of J. Patrick Kelly for its sponsored chair position at Wayne State University as one case in point: "Kelly worked for years on joint projects with Kmart and, not surprisingly, once he occupied the chair, engaged in research projects that benefited Kmart by saving the company millions of dollars" (p. 168). Of course, the larger issue reflected in such appointments involves the general appropriation of faculty research by corporatedriven agendas. Giroux correctly points out that increased corporate control over university policy and intellectual capital challenges the idea of the university as a democratic bastion of academic and intellectual freedom.

Further mirroring Aronowitz's recent book, Giroux's proposed solution to the corporate threat to universities involves reconstituting the idea of faculty as public intellectuals who convey their concerns beyond the dusty confines of academic life to a larger public audience. Rather than becoming "models of moral indifference" (p. 190), he argues that academics must connect student learning to social and ethical issues by embracing democratic learning practices that target the political and ideological landscape as primary units of analyses. On Giroux's view, effectively resisting the neo-liberal attack on universities also requires soliciting community support that understands, appreciates and advocates the democratic importance of academic freedom.

The Abandoned Generation: Democracy Beyond the Culture of Fear is an important text at this juncture in US and Canadian history, and during this period of shortsighted educational reform. Giroux marvelously articulates the concerns that so many educators express and provides concrete suggestions to address the appalling anti-democratic circumstances confronted by North American schools and 
universities. He generously, and perhaps over optimistically, reveals considerable faith in our collective ability as autonomous professionals and public intellectuals to recognize our social and ethical responsibility to protect the democratic ideals currently under siege in the prevailing culture of fear, and to resist the conservative opportunism this culture spawns. Although I am somewhat less optimistic than Giroux in our ability to transform these conditions, I wholeheartedly echo his sentiment that educators must diligently resist the neo-liberal naturalization of unbridled consumerism and the erosion of public spaces as inexorable historical outcomes. To answer this challenge effectively, as Giroux implores, we must defend public education and our universities for the contribution they make "to the quality of public life, fighting for the crucial role [they] play in asserting the primacy of democratic values over commercial interests, and providing students with the capacities they need for civic courage and engaged critical citizenship" (p. 197). 